\title{
Identifying University Minors to Support The Construction Specialization Area Within a Civil Engineering Technology Program
}

Vernon Lewis

Old Dominion University

Carol Considine

Old Dominion University, cconsidi@odu.edu

Follow this and additional works at: https://digitalcommons.odu.edu/engtech_fac_pubs

Part of the Business Commons, and the Engineering Education Commons

\section{Repository Citation}

Lewis, Vernon and Considine, Carol, "Identifying University Minors to Support The Construction Specialization Area Within a Civil Engineering Technology Program" (2007). Engineering Technology Faculty Publications. 119.

https://digitalcommons.odu.edu/engtech_fac_pubs/119

\section{Original Publication Citation}

Lewis, V., \& Considine, C. (2007). Identifying university minors to support the construction specialization area within a civil engineering technology program. Paper presented at the 2007 ASEE Annual Conference and Exposition, Honolulu, Hawaii.

This Conference Paper is brought to you for free and open access by the Engineering Technology at ODU Digital Commons. It has been accepted for inclusion in Engineering Technology Faculty Publications by an authorized administrator of ODU Digital Commons. For more information, please contact digitalcommons@odu.edu. 


\section{AC 2007-1805: IDENTIFYING UNIVERSITY MINORS TO SUPPORT THE CONSTRUCTION SPECIALIZATION AREA WITHIN A CIVIL ENGINEERING TECHNOLOGY PROGRAM}

\section{Vernon Lewis, Old Dominion University}

Vernon W. Lewis, JR. P.E., Senior Lecturer, is Program Director of Civil Engineering Technology at Old Dominion University. He joined the faculty of Old Dominion University in January 1994. He has 30 years of professional experience in consulting, industry and forensic engineering and is registered in eight states. His areas of expertise include structural design, contract documents and materials testing.

\section{Carol Considine, Old Dominion University}

Carol L. Considine is an Assistant Professor of Civil Engineering Technology at Old Dominion University. She joined the faculty of Old Dominion University in fall 1999. She has fifteen years of industrial experience in construction estimating and project management. She received her B.S. in Civil Engineering from Virginia Tech and her M.S. in Civil Engineering from the University of California at Berkeley. 


\title{
Identifying University Minors to Support the Construction Specialization area within a Civil Engineering Technology Program
}

\begin{abstract}
Construction programs at many universities are diversified and provide students with opportunities to examine topic areas that include mechanical and electrical systems, safety, business administration, residential construction, real estate, and management. It is impossible for small civil engineering technology programs with a construction emphasis to encompass all of these expertise areas. As industry looks for students with a knowledge base in these areas, it is incumbent upon programs to find avenues to provide these educational opportunities to their students.
\end{abstract}

To meet the upper division general education requirements for Old Dominion University, students must have either a minor, second major or a cluster, which is similar to a minor except that it is interdisciplinary in nature. Civil Engineering Technology (CET) students have historically taken advantage of minors that provide expertise in the areas of mechanical systems and engineering management. Both of these minors are offered by academic units which are housed in the same college as the CET program. Upon examination of minors available at the university in other academic units, it is apparent that additional expertise is available. This additional expertise can be found in the College of Health Sciences and the College of Business and Public Administration which offer minors in the areas of safety, business administration, real estate, and management.

The construction advisory committee for the CET program has examined the academic minors that are available in the College of Health Sciences and the College of Business and Public Administration and made recommendations regarding these minors. A CET Minor Recommendation Form has been developed as an outcome of the construction advisory committee recommendations. This paper examines the minor recommendations from that committee, examines the content of these minors, and evaluates the academic impact on students who may choose this route as a way to obtain knowledge in these specialized areas.

\section{Introduction}

Construction programs at many universities are diversified and provide students with opportunities to examine topic areas that include mechanical and electrical systems, safety, business administration, residential construction, real estate, and management. It is impossible for small civil engineering technology programs with a construction emphasis to encompass all of these expertise areas. As industry looks for students with a knowledge base in these areas, it is incumbent upon programs to find avenues to provide these educational opportunities to their students.

Old Dominion University (ODU) requires a second major, minor or cluster (a multidisciplinary minor) to meet the upper division general education requirements. Arguably this requirement 
may not meet the universal goal of general education, as it is not by definition a broadening experience for engineering students. All programs are currently under pressure to reduce the total student credit-hour requirements for graduation. It has been observed through interaction with the University Undergraduate Curriculum Committee that many programs have configured their choice of minors to include as many of the current curricular requirements as possible in order to meet the upper division general education requirement with a minimum commitment of credit hours. It should be noted that the minor chosen can not be in the same discipline as the major (CET majors can not take a CET minor at ODU), but often related minors include some of the courses that are required in the core curriculum from other departments making this requirement easier to meet with a minimum number of credit hours. Some minors specifically require that a minimum or six or more hours of additional work be taken beyond that included in the major, even though a significant number of the courses for the major and minor are the same.

An important aspect and perhaps a unique one about the program at Old Dominion University is the emphasis on problem-solving skills and the broadening of the program into non-traditional construction areas. Our roots in a traditional CET program provide the basis for problem-solving skills, while many other programs have departed from this paradigm and concentrate almost exclusively of construction-related coursework. A continuing goal is to expand the program further into non-traditional construction areas through the promotion of appropriate minors.

\section{Currently Recommended Minors}

This CET program has traditionally recommended either the Mechanical Engineering Technology (MET) minor or the Engineering Management (ENMA) minor. The requirements for each minor are given in Table 1 below. All courses are three credit hours:

\section{Table 1}

\begin{tabular}{|l|l|}
\hline MET Minor & Engineering Management Minor \\
\hline MET 305 - Fundamentals of Mechanics & ENMA 301 - Engineering Management \\
\hline MET 300 - Thermodynamics & ENMA 302- Engineering Economics \\
\hline MET 310 - Dynamics & ENMA 401 - Project Management \\
\hline MET 330 - Fluid Mechanics & $\begin{array}{l}\text { ENMA 420 - Statistical Concepts in Engineering } \\
\text { Management }\end{array}$ \\
\hline
\end{tabular}

For the MET minor, the only course that is not already included in the major is MET 300. For the ENMA minor, ENMA 302 is included in the curriculum, which leaves only the other three courses to be added. Assuming that one on these minors will be chosen, the typical curriculum sheet has blanks for three courses for a minor or cluster, and those selecting the MET minor must substitute two additional electives to complete all required credits. Currently the vast majority of CET students take one of the two minors discussed above. 
Both of these minors have disadvantages. The MET minor is very useful in supporting our department goal of enhancing students' problem-solving skills. However, it is not directly relevant to a construction emphasis. Although the ENMA minor certainly addresses management issues, it is more directly relevant to large industrial or governmental organizations and less applicable to the construction industry and construction project management. However, students are exposed to engineering economics and decision-making skills. Both of the above options are housed in the Batten College of Engineering and Technology.

\section{Additional Minor Options}

Students whom have graduated from the CET program and entered the construction industry have commented that the engineering management and mechanical engineering technology minor selections did not benefit them in their chosen career path and that minors that are more relevant to the construction industry business practices would probably serve them better. Based on this student feedback, the CET faculty reviewed available minors and found that additional expertise was available in other academic units such as the College of Health Sciences and the College of Business and Public Administration.

The College of Business and Public Administration offers the relevant minors in the areas of management, business administration and real estate. The College of Health Sciences offers an occupational safety minor. Descriptions of these minors are provided below:

- Management Minor - designed to develop the students understanding of management both as an art and a science, along with those administrative skills necessary for positions of leadership and responsibility. The management minor will allow students to function in a wide variety of organizational environments.

- Business Administration Minor - prepares students to advance in a broad range of careers in the public and private sectors. Students are exposed to accounting and economic principles as well as management, marketing and finance.

- Real Estate Minor - will enable students to develop practical skills in the area of real estate and investment. ${ }^{1}$ This minor would be beneficial for students interested in residential construction.

- Occupational Safety Minor - designed to prepare students to meet safety standards and guidelines in industry with the goal of managing operations to minimize financial losses resulting from accidents, health claims, legal actions and property damage. It is aimed at students who may reasonably anticipate safety as an additional duty. ${ }^{2}$

The CET faculty then examined the additional amount of credit hours required to complete these additional minor options. The results of this study are shown in Table 2 below. To students, an obvious disadvantage of these minors is that the total number of credit hours exceeds the minimum of 12 hours for the two previously recommended minors discussed above. Our perspective is that one's long-term goals should not be compromised, and that some of these minors may better meet the students' best interests and needs upon entering the construction industry. 
Table 2

Summary of Minors

\begin{tabular}{|c|c|c|}
\hline Courses & Minor Designation & Total Hours \\
\hline & Minor in Management & 18 \\
\hline \multirow[t]{2}{*}{ MGMT $325 *$} & Contemporary Organizations and Management & \\
\hline & plus 12 hours of 300-400 level management courses & \\
\hline MGMT 340 & Human Resources Management & \\
\hline MGMT 350 & Employee Relations Problems and Practices & \\
\hline MGMT 360* & Labor Management Relations & \\
\hline MGMT 361 & $\begin{array}{l}\text { International Business Operations (FIN 323, MKTG } \\
\text { 311, and MGMT 325) }\end{array}$ & \\
\hline MGMT 413 & Compensation Management(MGMT 340) & \\
\hline MGMT 414* & Collective Bargaining(MGMT 325 \& 360) & \\
\hline MGMT 417 & Employment Law (MGMT 325) & \\
\hline MGMT 418 & $\begin{array}{l}\text { Advanced Human Resources Management: } \\
\text { Contemporary Issues(MGMT } 325 \text { \& 340) }\end{array}$ & \\
\hline MGMT 451* & Organizational Behavior (MGMT 325) & \\
\hline \multirow[t]{2}{*}{ MGMT 452} & Organizational Development (MGMT 325 \& 451 & \\
\hline & Minor in Business Administration & 24 \\
\hline ACCT 201 & Principles of Accounting & \\
\hline \multirow[t]{2}{*}{ ECON 202S } & Principles of Microeconomics & \\
\hline & and five of the following courses: & \\
\hline ECON 201S & Principles of Macroeconomics & \\
\hline FIN 323 & Introductory Financial Management & \\
\hline MGMT 325 & Contemporary Organizations and Management & \\
\hline MKTG 311 & Marketing Principles and Problems & \\
\hline IT 360T & Principles of Information Technology & \\
\hline \multirow[t]{2}{*}{ OPMT 303T } & Operations Management and Technology & \\
\hline & Engineering Management & 12 \\
\hline ENMA 301 & Engineering Management & \\
\hline ENMA 302 & Engineering Economics & \\
\hline \multirow[t]{2}{*}{ ENMA 401} & Project Management & \\
\hline & and one of the following: & \\
\hline ENMA 420 & Statistical Concepts in Engineering Management & \\
\hline \multirow[t]{2}{*}{ ENMA 421} & Decision Theory in Engineering & \\
\hline & Minor in Occupational Safety & 15 \\
\hline ENVH 406 & Principles of Occupational Safety and Health & \\
\hline ENVH 407 & Occupational Safety Standards, Laws and Regulations & \\
\hline ENVH 425 & Occupational Safety and Health Program Management & \\
\hline ENVH 426 & Physical Hazards and their Control & \\
\hline
\end{tabular}




\begin{tabular}{|l|l|c|} 
& \multicolumn{1}{|c|}{ Mechanical Engineering Technology Minor } & $\mathbf{1 2}$ \\
\hline & \multicolumn{1}{|c|}{} & \\
\hline MET 300 & Thermodynamics & \\
\hline MET 305 & Fundamentals of Mechanics & \\
\hline MET 310 & Dynamics & $\mathbf{1 8}$ \\
\hline MET 330 & Fluid Mechanics & \\
\hline & \multicolumn{1}{|c|}{ Minor in Residential construction } & \\
\hline & \multicolumn{1}{|c|}{ Principles of Real Estate } & \\
\hline FIN 319 & Real Estate Finance(FIN 319 \& 323) & \\
\hline FIN 450 & Real Estate Investment Analysis(FIN 319 \& 323) & \\
\hline FIN 454 & and six hours from the following \\
\hline & Real Estate Appraisal (FIN 319 \& 323) & \\
\hline FIN 451 & Real Estate Market Analysis(FIN 319 \& 323) & \\
\hline FIN 458 & & \\
\hline
\end{tabular}

\section{Minors at Similar Institutions}

Virginia Polytechnic University and East Carolina University were researched to determine the availability of minors similar to those at Old Dominion University. ${ }^{1,2}$ It was determined that similar options were available at these universities also. Some of the available minors are shown in Table 3 below. Note that their total hours required for these minors are greater that those required for similar minors at Old Dominion University. Only the minor and total hours have been provided.

Table 3

\begin{tabular}{|c|c|}
\hline \multicolumn{2}{|c|}{ Minors at Virginia Polytechnic and State University } \\
\hline Minor Designation & Total Hours \\
\hline Global Business & 18 \\
\hline Business Administration & 27 \\
\hline Real Estate & 19 \\
\hline \multicolumn{2}{|c|}{ Minors at East Carolina University } \\
\hline Business Administration & 24 \\
\hline Worksite Health & 24 \\
\hline Public Administration & 24 \\
\hline Economics & 24 \\
\hline Planning & 24 \\
\hline
\end{tabular}




\section{Input from the CET Advisory Committee}

The CET advisory committee was consulted concerning on this issue during our fall 2006 meeting. The members reviewed the information above and recommended that we promote minors in areas other than MET and ENMA. The consensus of the committee was that the students should be encouraged to take the minor in Business Administration. Some members also recommended the minor in Occupational Safety since safety is integral to the construction process. Others had an interest in language; in consideration of the large number of productive Spanish-speaking workers currently is the construction workplace.

\section{Feedback from Students}

The subject of the choice of minor is often discussed during advising sessions. In past advising sessions prior to the tabulation of the requirements for alternate minors shown in Table 2, students often would arrive having given consideration to the other minors available, and with a decision made to pursue a minor rather than MET or ENMA. Some have other interests driving the choice of minor, such as alternate career issues in a non-technical area, but most have interest in a technical or business area. Most had not determined the number of semester hours required to complete their choice of minor. However, often when the minor is examined carefully, the student finds that a significant increase in the semester hours required beyond that required by MAT or ENMA resulting in a decision not to follow these minors.

It then becomes incumbent upon advisors to encourage students to think beyond the minimum requirements and more about what is best for their career. A possible future development in this area may be to encourage the School of Business to consider the addition of a new minor that remains meaningfully directed toward construction but that can be completed within 12 semester hours.

\section{Conclusion}

A CET Minor Recommendation Form has been prepared for distribution to students. This form included the information shown in Table 2 above, in addition to introductory information about the minors and our rationale for the change. The implementation will take some time, as many students are currently committed to the MET or ENMA minors. All students are advised each semester at which time this program will be introduced to the student body.

The CET program has committed to promoting minors in Business and other areas for majors interested in Construction Management. At the current time the University is in the process of reviewing its upper-division general education requirements. It is currently not known how or if the current requirements will be changed, but it is hoped that these requirements will be relaxed at the upper division, providing curricular "space" for additional hours in the standard curriculum for courses meeting minor requirements. Of course, to satisfy ABET requirements, ENMA, Engineering Economics must remain part of the curriculum for the foreseeable future.

In the event this relaxation of the requirements does not occur, it is possible that courses common to one or more minors such as Management 325 could become a permanent part of the 
curriculum, thereby supporting a shift to minors more applicable to students in the construction management emphasis.

Bibliography

1. http://bpa.odu.edu/bpa/academics/advising/MINORS1.pdf, Accessed March 2, 2007.

2. http://hs.odu.edu/commhealth/academics/bs_enviro/minors.shtml, Accessed March 2, 2007.

3. http://www.undergradcatalog.registrar.vt.edu/0607/colleges.html, Accessed March 6, 2007

4. http://www.ecu.edu/cs-acad/aa/upload/UgCat0607-4.pdf, Accessed March 6, 2007 